\title{
Expert Meeting Report: Achieving the Best Installed Performance from High- Efficiency Residential Gas Furnaces
}

Larry Brand

Partnership for Advanced Residential Retrofit (PARR)

March 2012 


\begin{abstract}
NOTICE
This report was prepared as an account of work sponsored by an agency of the United States government. Neither the United States government nor any agency thereof, nor any of their employees, subcontractors, or affiliated partners makes any warranty, express or implied, or assumes any legal liability or responsibility for the accuracy, completeness, or usefulness of any information, apparatus, product, or process disclosed, or represents that its use would not infringe privately owned rights. Reference herein to any specific commercial product, process, or service by trade name, trademark, manufacturer, or otherwise does not necessarily constitute or imply its endorsement, recommendation, or favoring by the United States government or any agency thereof. The views and opinions of authors expressed herein do not necessarily state or reflect those of the United States government or any agency thereof.
\end{abstract}

Available electronically at http://www.osti.gov/bridge

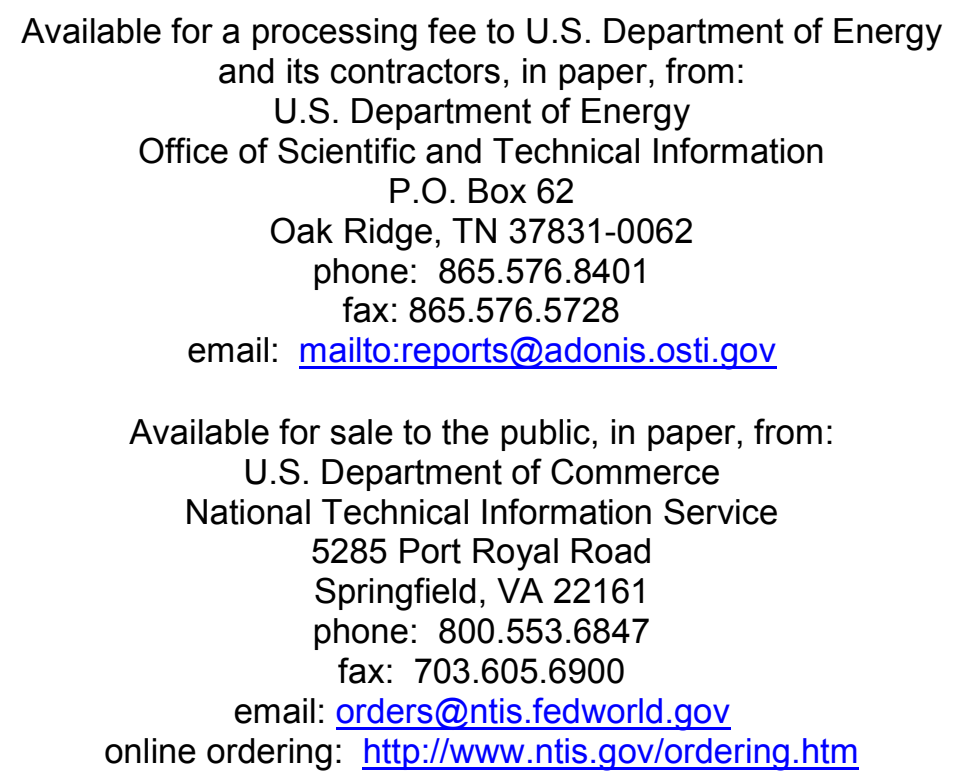

Printed on paper containing at least $50 \%$ wastepaper, including $20 \%$ postconsumer waste 


\title{
Expert Meeting Report: Achieving the Best Installed Performance from High-Efficiency Residential Gas Furnaces
}

\author{
Prepared for: \\ Building America \\ Building Technologies Program \\ Office of Energy Efficiency and Renewable Energy \\ U.S. Department of Energy \\ Prepared by: \\ Larry Brand \\ Partnership for Advanced Residential Retrofit \\ Gas Technology Institute \\ 1700 South Mount Prospect Road \\ Des Plaines IL 60018 \\ Technical Monitor: Stacey Rothgeb \\ Task Order KNDJ-0-40346-02
}

March 2012 
[This page left blank] 


\section{Contents}

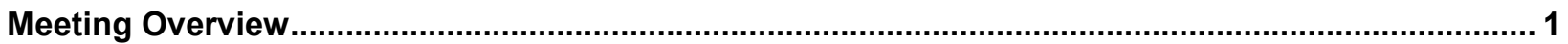

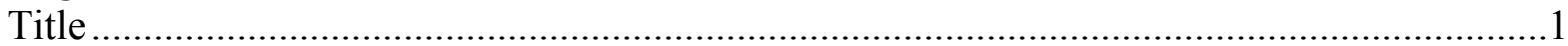

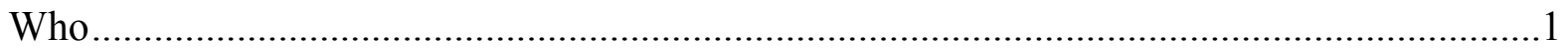

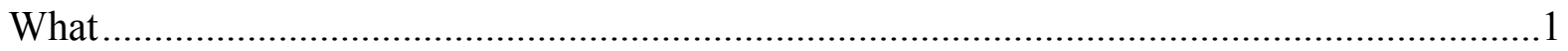

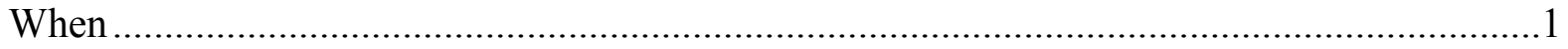

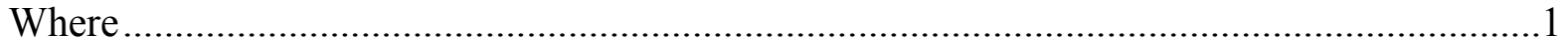

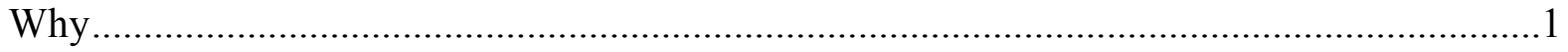

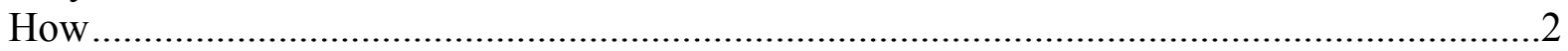

Attendees

Agenda

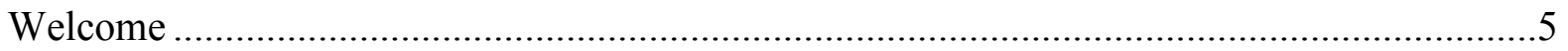

Presentation 1 - U.S. DOE Building America Overview..............................................6

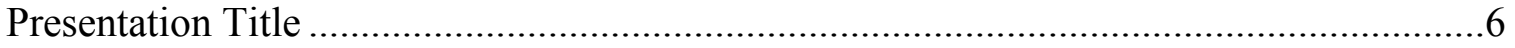

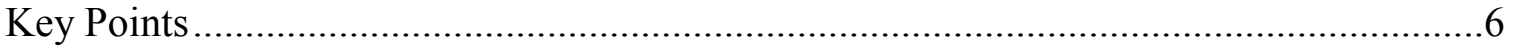

Presentation 2 - Introduction to PARR .....................................................................6

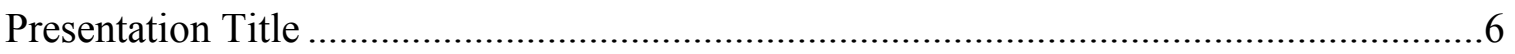

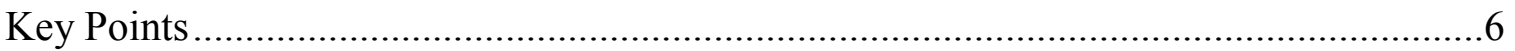

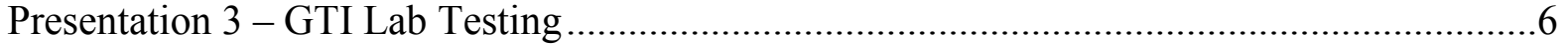

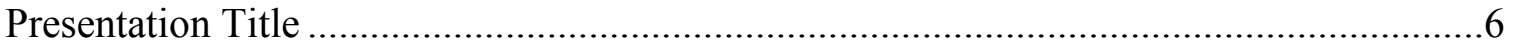

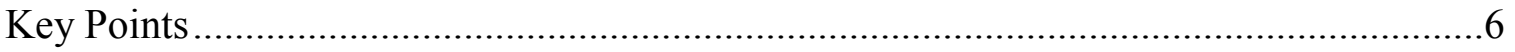

Presentation 4 - National Laboratory Perspective ..................................................... 7

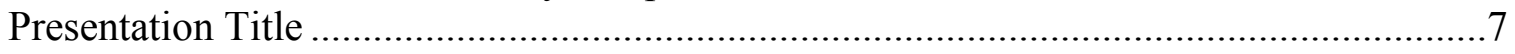

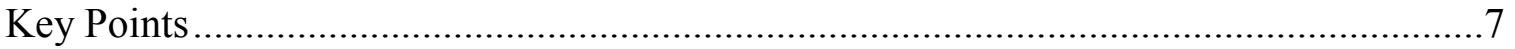

Presentation 5 - Expert Manufacturer Advice - Carrier ..............................................

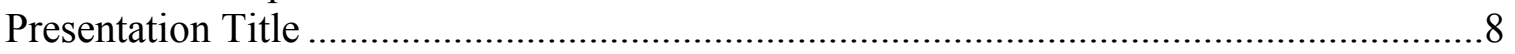

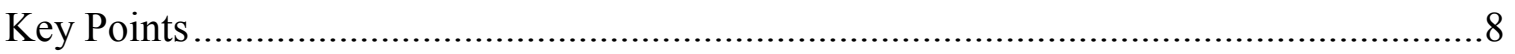

Presentation 6 - Expert Manufacturer Advice - Trane ..................................................... 9

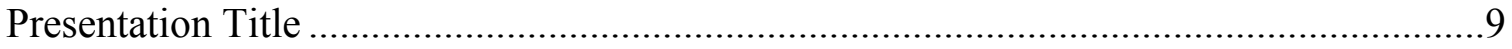

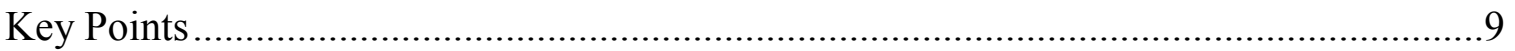

Presentation 7 - Expert Installer Advice from Bartholomew Heating and Cooling...............10

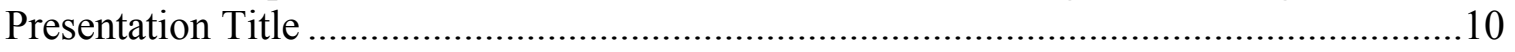

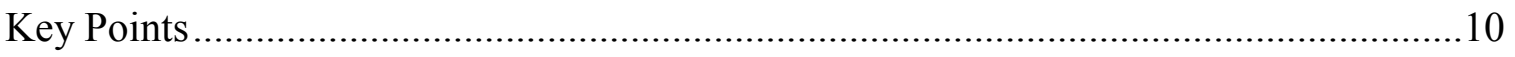

Presentation 8 - Measuring Air Handler Flow in the Field ............................................ 11

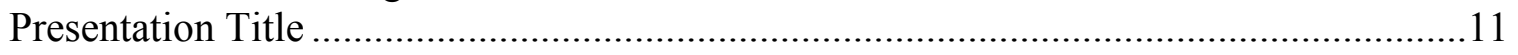

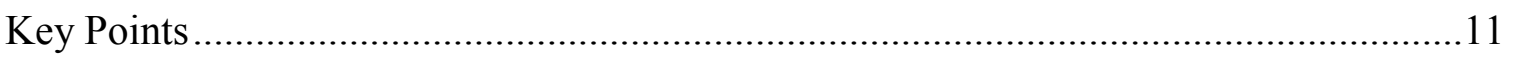

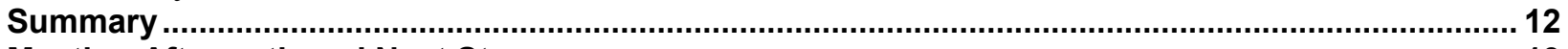

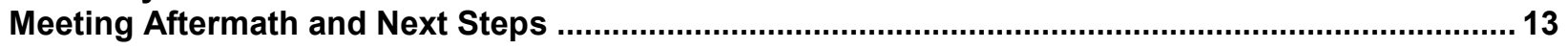

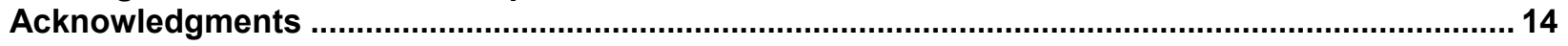

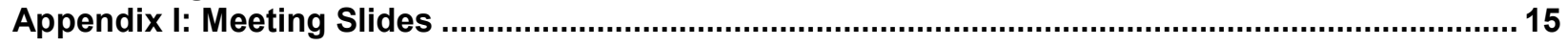

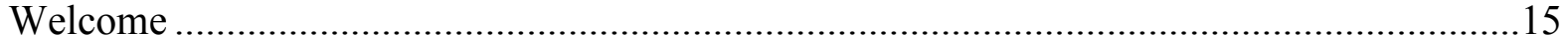

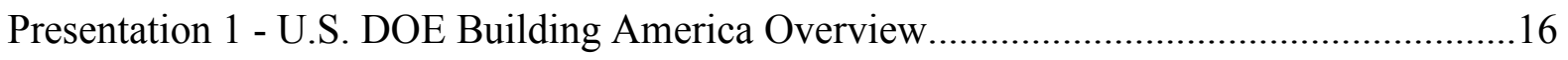

Presentation 2 - Introduction to PARR ......................................................................... 16

Presentation 3 - GTI Lab Testing ................................................................................. 17

Presentation 4 - National Laboratory Perspective ........................................................... 17

Presentation 5 - Expert Manufacturer Advice - Carrier .................................................. 18

Presentation 6 - Expert Manufacturer Advice - Trane .................................................... 18 


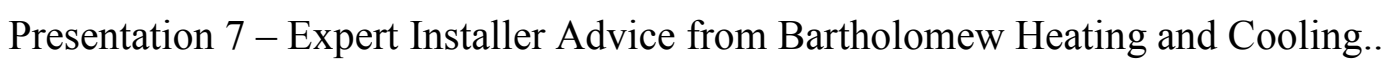

Presentation 8 - Measuring Air Handler Flow in the Field ............................................19

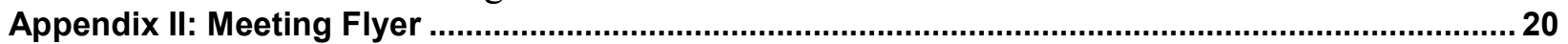

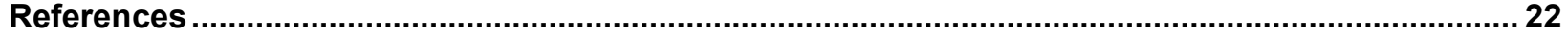




\section{Definitions}

ACCA

AFUE

AHRI

ASHRAE

HVAC

NFPA
Air Conditioning Contractors of America

Annual Fuel Utilization Efficiency

Air Conditioning, Heating, and Refrigeration Institute

American Society of Heating, Refrigeration and Air

Conditioning Engineers

Heating, Ventilation, and Air Conditioning

National Fire Protection Association 


\section{Meeting Overview}

\section{Title}

Achieving the Best Installed Performance from High-Efficiency Residential Gas Furnaces

\section{Who}

The Partnership for Advanced Residential Retrofit (PARR) invited industry experts from Building America (BA), Building America research teams, manufacturers, HVAC installers, national laboratories, DOE, and PARR partners. A total of 33 individuals from 18 organizations participated in the meeting (see list).

\section{What}

The objective of this Expert Meeting is to identify installation practices that provide the best installed efficiency for residential gas furnaces, explain how AFUE and field efficiency can differ, and investigate the impact of installation practices on the efficiency and long-term durability of the furnace.

\section{When}

Thursday July 28,$2011 ; 1: 00$ p.m. to 4:00 p.m. Central

\section{Where}

This meeting was conducted via webinar. Many participants were not able to travel to make their presentations.

\section{Why}

In Building America research, there is an often-identified gap between predicted energy savings according to the Energy Plus or BEopt models and the actual energy savings of the home. In cold climates with gas warm-air furnaces as the primary heating system type, the largest energy savings measure is often upgrading the furnace from mid to high-efficiency. PARR is developing a measure guideline to provide information and guidance to the research community and installing contractors so that the installed performance of high-efficiency furnaces is as close as possible to the modeled or rated performance. As a corollary, PARR's laboratory-based research into furnace performance will identify gaps related to

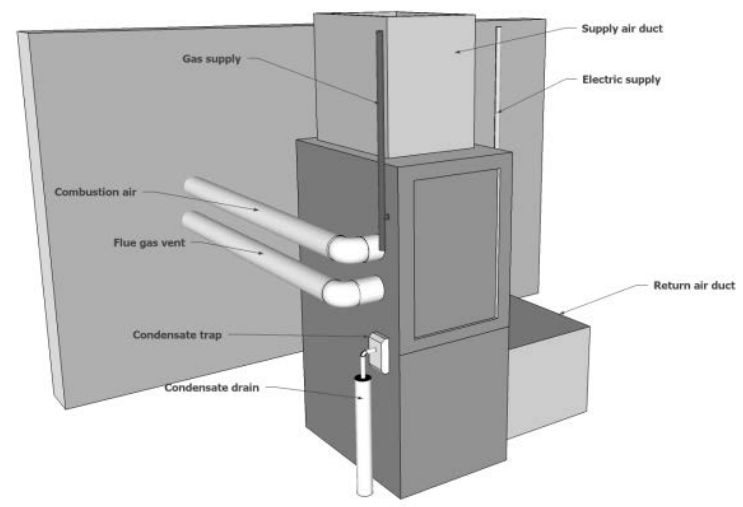
part-load performance and installation variability that may result in changes in the rating standard or the algorithm used in the models.

Currently, PARR is testing three types of high-efficiency furnaces in the laboratory under several installation scenarios. These tests are expected to show how variations in furnace type and installation practices can impact AFUE when measured according to ASHRAE standard 103. PARR and several BA teams are also conducting field-efficiency tests under less-controlled 
conditions. In this Expert Meeting, speakers from the Gas Technology Institute, furnace manufacturers, an installing contractor, Oak Ridge National Laboratory, and the University of Illinois Building Research Council provided their perspectives on methods to achieve the best installed performance.

Research questions addressed:

\section{How do installed efficiency and AFUE differ?}

2. What are common installation issues affecting efficiency and how are they addressed?

\section{How do researchers evaluate field performance?}

\section{What type of furnace gives the best performance in difficult installations?}

\section{How}

Expert Meetings are designed to be an interactive experience, where all participants contribute in substantive ways. Representatives from manufacturers, identified with the assistance of the Air Conditioning, Heating and Refrigeration Institute (AHRI), and other panel members were chosen to discuss several unique perspectives on the issue of installed performance. Panel members, listed below, included NREL, manufacturers, researchers, and an installing contractor.

This report contains the first page of each presenter's slides in Appendix I. Full presentations and webinar recording are provided at: http://www.baparr.net and accompany this report on the NREL website: http://www1.eere.energy.gov/buildings/building_america/meetings.html.

\begin{tabular}{|l|l|l|}
\hline Panel Member & Company & Title \\
\hline Brad Bartholomew & $\begin{array}{l}\text { Bartholomew Heating and } \\
\text { Cooling }\end{array}$ & Owner \\
\hline $\begin{array}{l}\text { Bio: Brad Bartholomew is the Owner of Bartholomew Heating and Cooling, an installing } \\
\text { contractor in Kalamazoo Michigan. He is also a BPI and RESNET certified energy auditor. }\end{array}$ & R\&D Manager \\
\hline Larry Brand & Gas Technology Institute & $\begin{array}{l}\text { Bio: Larry Brand is an R\&D Manager at Gas Technology Institute and Principal } \\
\text { Investigator for the Partnership for Advanced Residential Retrofit Building America team. } \\
\text { He has an MSME from U of Illinois and has been working in R\&D management for the } \\
\text { residential sector for 25 years, including development of a new furnace, boiler, and wall } \\
\text { furnace. }\end{array}$ \\
\hline $\begin{array}{l}\text { Paul Francisco } \\
\text { University of Illinois Building } \\
\text { Research Council }\end{array}$ & Research Specialist \\
\hline $\begin{array}{l}\text { Bio: Paul Francisco is a Research Specialist at the Building Research Council at the } \\
\text { University of Illinois - Urbana-Champaign. Paul's research focuses on field evaluations of } \\
\text { the last 15 years on airflow in forced-air distribution systems. }\end{array}$ \\
\hline
\end{tabular}




\begin{tabular}{|l|l|l|}
\hline Panel Member & Company & Title \\
\hline Paul Haydock & United Technologies Carrier & $\begin{array}{l}\text { Manager of Heating } \\
\text { Products }\end{array}$ \\
\hline
\end{tabular}

Bio: Paul Haydock is Manager of Heating Products at United Technologies Carrier. He has an MS in Mechanical Engineering from Purdue and has 22 years' experience in gas furnace development; the last 16 years with Carrier where he is currently a manager of condensing furnace development. A 22-year member of ASHRAE, he was a voting member on the ASHRAE Standard Project Committee, SPC103-1993R, which is basis for the DOE AFUE testing standard.

\begin{tabular}{|l|l|l|}
\hline Steven Kowalski & Trane & Engineering Manager \\
\hline
\end{tabular}

Bio: Steven Kowalski is the Manager of Furnace, Electrical, and Power Electronics Component Engineering at Trane where he has 16 years gas furnace development experience. He has an MS in Mechanical Engineering from Princeton University and is working on his MBA from Indiana University. Steve has been involved with ASHRAE for 15 years and was also a voting member of SPC 103.

\begin{tabular}{|l|l|l|}
\hline Jeffrey Munk & $\begin{array}{l}\text { Oak Ridge National } \\
\text { Laboratory }\end{array}$ & Research Staff \\
\hline
\end{tabular}

Bio: Jeffrey Munk is a member of the Building Equipment research group at ORNL. He has been working with ground source heat pumps for space conditioning and water heating at experimental research houses for the past year and a half. He has 5 years of industry experience working for Carrier Corporation on residential packaged products and gas furnaces in the areas of product development and problem resolution. He has a B.S. and M.S. degree in Mechanical Engineering from Purdue University.

\begin{tabular}{|l|l|l|}
\hline Stacey Rothgeb & $\begin{array}{l}\text { National Renewable Energy } \\
\text { Laboratory }\end{array}$ & Chief Engineer \\
\hline
\end{tabular}

Bio: Stacey Rothgeb is the PARR Building America Research Coordinator at the National Renewable Energy Laboratory.

\begin{tabular}{|l|l|l|}
\hline Jim VerShaw & Trane & Chief Engineer \\
\hline \multicolumn{2}{|l|}{ Bio: Jim VerShaw is Chief Engineer, Residential Solutions at Trane. } \\
\hline
\end{tabular}




\section{Attendees}

\begin{tabular}{|l|l|}
\hline Attendees & Organization \\
\hline Jim Barnet & Rheem \\
\hline Brad Bartholomew & Bartholomew Heating and Cooling \\
\hline Larry Brand & Gas Technology Institute \\
\hline John Busse & ECR International \\
\hline Cheryn Engebrecht & National Renewable Energy Laboratory \\
\hline Xia Fang & National Renewable Energy Laboratory \\
\hline David Fletcher & Rheem \\
\hline Paul Francisco & University of Illinois Building Research Council \\
\hline Alea German & Davis Energy Group \\
\hline Mike Gestwick & National Renewable Energy Laboratory \\
\hline Paul Haydock & United Technologies Carrier \\
\hline Brian Holton & Ferris State University \\
\hline Diane Jakobs & Rheem \\
\hline Mike Keesee & Sacramento Municipal Utility District \\
\hline Steve Kowalski & Trane \\
\hline David Mallay & NAHB Research Center \\
\hline Jason Mauric & Ferris State University \\
\hline Arn Mcintyre & Ferris State University \\
\hline Marcus Metoyer & Michigan State University \\
\hline Jeffrey Munk & Oak Ridge National Laboratory \\
\hline Tom Pallett & Nordyne \\
\hline John Palmatary & Rheem \\
\hline Srikanth Puttagonta & Steven Winter Associates \\
\hline Stacey Rothgeb & National Renewable Energy Laboratory \\
\hline Michelle Rowland & National Renewable Energy Laboratory \\
\hline Bill Roy & Carrier \\
\hline Shawn Scott & Gas Technology Institute \\
\hline William Smith & Rheem \\
\hline Frank Stanonik & Air Conditioning, Heating, and Refrigeration Institute \\
\hline Jim VerShaw & Trane \\
\hline Jared Wells & Midwest Energy Efficiency Alliance \\
\hline Jon Winkler & National Renewable Energy Laboratory \\
\hline & \\
\hline
\end{tabular}




\section{Agenda}

\begin{tabular}{|c|c|c|}
\hline Topic & Presenter & Time (central time) \\
\hline Welcome & Larry Brand, GTI & 1:00 p.m. \\
\hline Introduction to Building America & Stacey Rothgeb, NREL & $1: 00-1: 05$ \\
\hline $\begin{array}{l}\text { Introduction to the Partnership for } \\
\text { Advanced Residential Retrofit }\end{array}$ & Larry Brand, GTI & $1: 05-1: 10$ \\
\hline $\begin{array}{l}\text { PARR High Efficiency Furnace } \\
\text { Testing - Test Plan, Results to } \\
\text { Date, Future Plans }\end{array}$ & Larry Brand, GTI & $1: 10-1: 30$ \\
\hline $\begin{array}{l}\text { Expert National Lab Advice - } \\
\text { How to Get the Best Installed } \\
\text { Performance - Lessons from the } \\
\text { Lab }\end{array}$ & $\begin{array}{l}\text { Jeff Munk, Oak Ridge } \\
\text { National Laboratory }\end{array}$ & $1: 30-1: 50$ \\
\hline Q\&A & & $1: 50-2: 00$ \\
\hline $\begin{array}{l}\text { Expert Manufacturer Advice - } \\
\text { How to Get the Best Installed } \\
\text { Performance }\end{array}$ & Paul Haydock, Carrier; & $2: 00-2: 20$ \\
\hline $\begin{array}{l}\text { Expert Manufacturer Advice - } \\
\text { How to Get the Best Installed } \\
\text { Performance }\end{array}$ & $\begin{array}{l}\text { Steve Kowalski/Jim } \\
\text { VerShaw, Trane }\end{array}$ & $2: 20-2: 40$ \\
\hline Manufacturer Q\&A & & $2: 40-3: 00$ \\
\hline $\begin{array}{l}\text { Expert Installer Advice }- \text { How to } \\
\text { Get the Best Installed Performance } \\
\text { - Lessons from the Field }\end{array}$ & $\begin{array}{l}\text { Brad Bartholomew, } \\
\text { Bartholomew Heating and } \\
\text { Cooling }\end{array}$ & $3: 00-3: 20$ \\
\hline $\begin{array}{l}\text { Expert Field Measurement Advice } \\
\text { - Measurement of Air Handler } \\
\text { Flow in the Field }\end{array}$ & $\begin{array}{l}\text { Paul Francisco, University } \\
\text { of Illinois Building } \\
\text { Research Council }\end{array}$ & $3: 20-3: 40$ \\
\hline Q\&A and Discussion & & $3: 40-3: 55$ \\
\hline Conclusion & & $3: 55-4: 00$ \\
\hline
\end{tabular}

\section{Welcome}

Larry Brand from the Gas Technology Institute welcomed the panel and participants and introduced the topic of the Expert Meeting: "Achieving the Best Installed Performance from High-Efficiency Residential Gas Furnaces." He indicated that the webinar was presented by the Partnership for Advanced Residential Retrofit team on behalf of the U.S. Department of Energy's Building America program. He mentioned that the speakers will focus on how to identify installation practices that provide the best efficiency for residential gas furnaces, explain how AFUE and field efficiency can differ, and investigate the impact of installation practices on the long-term performance of the furnace.

Larry introduced each speaker in turn. Questions and responses are included in the key points for each presentation. 
Presentation 1 - U.S. DOE Building America Overview

Stacey Rothgeb, Research Coordinator at the National Renewable Energy Laboratory, presented an overview of the Building America program.

\section{Presentation Title}

Building America Program Introduction

\section{Key Points}

The BA program was created to reduce energy use through a building science and system engineering approach. The primary goal of the research is to create cost-effective, least-cost, and highest-value solutions. The secondary goal of the research is to develop whole systems knowledge to clearly understand cost/performance tradeoffs, identify and resolve knowledge gaps, and clearly define stakeholders' needs. A third goal of the research is to produce continuous evaluation and performance feedback on measure guidelines, measures database, audit and analysis tools, and test houses and community-scale performance data. In 2011, there are 15 Industry Research Teams addressing both new construction and retrofit.

\section{Presentation 2 - Introduction to PARR}

Larry Brand, R\&D Manager at the Gas Technology Institute, presented an overview of the PARR team.

\section{Presentation Title}

Introduction to PARR

\section{Key Points}

The Partnership for Advanced Residential Retrofit (PARR) is a Midwest Building America team with a Chicago hub with a concentration on residential retrofit. PARR and its five research team members focus on systems and whole home solutions in cold climates targeting high potential building stock with opportunities for energy savings and scalability. PARR is led by the Gas Technology Institute (GTI). GTI is a not-for-profit with a 65-year history in energy R\&D including residential and commercial buildings. The other four PARR team members are CNT Energy, the Midwest Energy Efficiency Alliance, the University of Illinois Building Research Council, and Future Energy Enterprises. PARR partners include 40 industry members from manufacturers, developers, utilities, EE program implementers, government agencies and neighborhood organizations. PARR is active in five research areas in Building America for 2011.

\section{Presentation 3 - GTI Lab Testing}

Larry Brand from the Gas Technology Institute presented recent laboratory research on condensing furnaces.

\section{Presentation Title}

Installed Performance of High Efficiency Gas Furnaces - GTI Lab Testing

\section{Key Points}

The installed performance of residential gas furnaces and the AFUE rating number can be quite different. These differences come from the AFUE test requirements and the environment and the home. AFUE is tested in a very controlled laboratory setting without ductwork and with very accurate instruments. AFUE is also tested with standard oversizing of $70 \%$. The conditions in a 
home are generally uncontrolled. Residential duct work can be significantly undersized and it can be very difficult to get accurate measurements in the field. In addition, residential furnaces can be significantly oversized for the application.

ASHRAE standard 103-2007 is the current consensus standard used for testing AFUE. DOE uses a version of that standard in the labeling process (Title 10). GTI (through PARR) is using the ASHRAE test method as the basis for identifying performance degradation associated with oversizing, high static pressure, and high pressure drop filters. PARR is testing three types of furnaces and will make recommendations on the best type for particular installation issues found in the field - over-sized furnace, undersized ducts, and using high efficiency filters. PARR will report on efficiency degradation and blower power requirements under these scenarios.

Key takeaways from this presentation were:

1. GTI believes AFUE will vary a few percent with over-sizing up to twice the load and distribution system deficiencies will not impact AFUE.

2. Undersized ducts and high efficiency filters will have a significant impact on fan power requirements. The extent of the impact will be determined in the research project.

3. Among the three furnace types being tested, single stage furnaces are the most costeffective option for broad application, two stage furnaces provide improved efficiency and air mixing with properly sized distribution systems, and modulating furnaces are the best solution for undersized distribution systems.

\section{Presentation 4 - National Laboratory Perspective}

Jeffrey Munk from Oak Ridge National Laboratory (ORNL) presented a compilation of research from the national labs.

\section{Presentation Title}

Lessons from the Lab

\section{Key Points}

Reducing losses to the unconditioned space is the top installation best practice. Losses can be minimized by moving equipment inside the envelope or extending the envelope around the equipment if installed outside the conditioned space, and then sealing and insulating everything including the ductwork and blower compartment. Preheating combustion air from $30^{\circ} \mathrm{F}$ to $150^{\circ} \mathrm{F}$ can provide a 1\% improvement in AFUE at some cost. Using indoor air creates an infiltration penalty of $0 \%$ to $3 \%$ and is often overlooked in the efficiency analysis.

Furnace part-load efficiency was studied extensively in the 80's and 90's by DOE and NIST. The analysis was largely done on furnaces with standing pilots. That information shows a very flat profile down to $10 \%$ of full load and then a significant drop to zero. BEopt uses a linear relationship dropping to $80 \%$ of steady state performance at a part load factor of 0 from $100 \%$ of steady state performance at a part load factor of 1 . Two-stage and multistage AFUE is controlled by the amount of time the furnace operates on lower stages (better performance at low stages). 
Key takeaways from this presentation were:

1. There is an infiltration penalty of up to $3 \%$ associated with furnaces that use indoor air for combustion - largely overlooked in the AFUE calculation and the models.

2. Part-load performance of newer-designed furnaces has not been tested. Algorithms to update furnace performance based on those test results need to be developed for the building modeling tools.

3. Fan power requirements at part load also need to be developed for the building modeling tools to properly reflect electric energy consumption.

\section{Presentation 5 - Expert Manufacturer Advice - Carrier}

Paul Haydock, Engineering Manager from United Technologies - Carrier, presented a manufacturers perspective on the issue.

\section{Presentation Title}

Expert Manufacturer Advice - How to Get the Best Installed Performance

\section{Key Points}

Paul presented some advice on three topics: oversizing, installation location and combustion air, and vent and combustion air pipe sizing.

On oversizing, the Air Conditioning Contractors of America (ACCA) recommend 0\% to 40\% over-sizing to meet the needs of the occupants and avoids higher costs, greater energy consumption, and wear and tear on the equipment associated with frequent cycling. The DOE and ASHRAE AFUE calculation uses $70 \%$ oversize to determine the cycling time - a mis-match perhaps based on older equipment. Oversizing provides extra capacity to meet peak heating loads and to recover from setback, which generally saves $15 \%$ of energy for an 8 hour $10^{\circ} \mathrm{F}$ setback. Reducing the amount of oversizing provides better comfort (temperature swings), better air mixing, and less wear and tear on the furnace.

Paul agreed with the ORNL presenter regarding locating the furnace inside the conditioned space to reduce heat loss, but added some information on other options. Outdoor furnaces are weatherized and the rating deducts for heat loss from the jacket to the outdoor environment. These furnaces have no infiltration loss because they use outdoor air for combustion. Isolated combustion systems are not weatherized and a deduction is made for jacket loss as well with the assumption that they can be installed in crawl spaces or attics. The assumption for these products is that outdoor air is used for combustion through a direct-vent configuration or installation in an attic or crawl space that communicates with the outdoors. Thus, there is no infiltration load.

Vent and combustion air sizing guidelines are provided in the manufacturers installation instructions. Using the minimum diameter for run of equivalent length moves less air (because of the pressure switch controls) and uses less fan power. Locate vent pipes in the conditioned space as much as possible to transfer some of the unused waste heat in the vent pipe. 
Key takeaways from this presentation were:

1. Oversizing reduces comfort, performance, and furnace life at the expense of faster recovery from setback and meeting the heating load under extreme conditions. Better sizing techniques in alignment with the ACCA recommendations should be used to reduce energy consumption. ASHRAE should consider revising the AFUE test method to use $40 \%$ over-sizing.

2. Both outdoor furnaces and Isolated Combustion Furnaces are rated assuming outdoor air for combustion is provided. Installation instructions for Isolated Combustion Furnaces only recommend (but not require) outdoor air for combustion, so there is a discrepancy in the ratings.

\section{Presentation 6 - Expert Manufacturer Advice - Trane}

Steve Kowalski, Engineering Manager from Trane, presented his perspective on the issue. Jim VerShaw, Chief Engineer from Trane, contributed to the material but did not present.

\section{Presentation Title}

Expert Manufacturer Advice - How to Get the Best Installed Performance

\section{Key Points}

Steve Kowalski presented information on several aspects of the problem: latent heat gain, temperature rise, external static pressure, fan power, and selecting the right product.

Latent heat gain is measured in the lab under carefully controlled steady-state and cyclic conditions. This measurement is too difficult to do in the field, so field measurements will not include contribution from this part of the test. Installers will get the best field efficiency by setting the proper air flow and external static pressure as listed in the manufacturers' installation instructions.

Steady state efficiency decreases with increasing temperature rise at about $1 \%$ per $15^{\circ} \mathrm{F}$ increase in rise. Install with the lowest rise allowed on the nameplate to get the best performance but beware of homeowner complaints.

ASHRAE 103 prescribes external static pressure at 0.2 inches water column, not very realistic in the field. PSC motors may need to be re-wired on the control board to meet the temperature rise requirements thereby increasing the amount of energy used for fan power. ECM furnaces automatically adjust to maintain air flow and by corollary temperature rise unless there is an unusual condition such as a blocked duct or filter. Under high static conditions (undersized ducts), the tradeoff is between an ECM, which will maintain airflow at the expense of blower watts, and the PSC, which will not maintain airflow, but at least won't have the increased blower watts. Unfortunately, the reduction in air flow for PSC motors under high static pressure contradicts the advice for maintaining the highest gas furnace efficiency (above). It has been reported by others that in very undersized duct systems ECM motors may use more fan power. Testing is needed to verify this assumption.

Comfort versus efficiency - As we've already discussed, there is a tradeoff between installed efficiency and comfort. Within the allowable temperature rise limits, lower temperature rise will 
give higher installed efficiency at the price of reduced comfort (cold blow). Within the allowable temperature rise limits, higher temperature rise will give better comfort at the price of a small decrease in installed efficiency. The overriding concern, however, is to make sure the installation is within the allowable temperature rise as stated on the furnace nameplate.

Selecting the right furnace for the job also requires making tradeoffs. For high static conditions, the main tradeoff is between gas use and electric power consumption. An ECM blower motor will maintain airflow, which will result in maintaining furnace efficiency at the expense of increased blower watts. A PSC motor will not maintain airflow, which will reduce furnace efficiency but blower power with PSC motors also decreases at high static. The tradeoff may be a comparison between the relative price of gas energy and electric energy at the site. Electric energy consumed by the blower is only a fraction of the amount of energy that is used in the form of gas energy, so improvements in gas efficiency are generally advantageous - favoring ECM motors for high static conditions.

Key takeaways from this presentation were:

1. The lowest temperature rise across the furnace produces the best efficiency but also the most complaints from occupants. Changing occupant behaviors and expectations can improve installed efficiency by $1 \%$ or $2 \%$. In a comment provided after the meeting, relocating or selecting air diffusers that better spread the jet can have a beneficial effect for systems that have low temperature rise such as heat pumps.

2. To get the best applied efficiency in terms of fan power, maintain external static pressure as low as possible through larger sized ducts. Testing is needed to determine fan power versus external static pressure for the three furnace types.

3. There is a tradeoff between the best thermal efficiency and the best blower power. Thermal efficiency is best at minimum temperature rise across the furnace, usually accomplished by increasing the air flow and static pressure. Minimum blower power is achieved by maintaining the lowest air flow and static pressure for ECM motors and the opposite for PSC motors. An analysis of tradeoffs between these two factors based on local gas and electric prices is needed to identify an optimum operating condition.

\section{Presentation 7 - Expert Installer Advice from Bartholomew Heating and Cooling}

Brad Bartholomew, Owner of Bartholomew Heating and Cooling presented tips and guidelines from the installer perspective.

\section{Presentation Title}

Keys to Achieving the Best Installed Performance from High Efficiency Furnaces

\section{Key Points}

Brad Bartholomew presented information on common field problems encountered and solutions that have worked for his team.

A key problem area is poor installation practices caused by not following the manufacturer's installation instructions for gas pressure adjustments, vent sizing, filter sizing, temperature rise, and static pressure testing. The solution is to improve training and awareness of the importance 
of these areas to achieve the best installed performance. A commissioning report left with the homeowner is recommended to show all steps have been taken for the setup and what remedial measures are needed. ACCA Quality Installer (QI) techniques should be followed.

Improper equipment and duct sizing can be addressed by installer training and proper use of ACCA manuals. Duct systems that are undersized create high static and temperature rise issues which lead to comfort issues, noise, and temperature swings. A typical problem is undersized return air systems requiring additional return lines from the trunk to the furnace. Leaky and poorly insulated ducts do not impact the furnace efficiency, but they do lose heat to the unconditioned space. Air sealing of ductwork is recommended.

Key takeaways from this presentation were:

1. Proper installer training on set-up of furnaces can significantly impact installed performance: external static pressure as low as possible, reducing the rise to the minimum allowed, and adding return duct drops are key elements.

2. Additional steps to seal and insulate ducts, while not impacting furnace efficiency, will reduce losses to the unconditioned space and reduce energy consumption - which is equally important to the homeowner.

3. A written commissioning report shared with the homeowner documents adjustments made installation and identifies areas that need remedial attention.

4. Handheld combustion analyzers have limitations in accuracy and are not useful for measuring the efficiency of condensing furnaces, due to the significant latent component. Another field method is needed.

\section{Presentation 8 - Measuring Air Handler Flow in the Field}

Paul W. Francisco, Researcher with the University of Illinois Building Research Council presented the results of his research on measuring air flow in the field.

\section{Presentation Title}

Air Handler Flow Measurement: What Works and What Doesn't

\section{Key Points}

Measuring air volume is important to assess the adequacy of flow across coils for heat pumps and cooling and to assist in diagnosing problems such as cycling on a limit switch, undersized ducts, and poor dehumidification in the cooling season. Five techniques were identified and the pros and cons of each method were reviewed:

1. Pitot traverse - difficult to perform in the field; large user error

2. External static pressure measurement - pressures can vary widely within plenums. In many field installations (such as those with bypass humidifiers or those with radial duct systems) there is not even a place to measure the static pressure that would represent the entire air flow. 
3. Temperature rise/drop - supply temperatures can be poorly mixed. Accuracy is approximately $30 \%$.

4. Calibrated fan assist - most accurate but time consuming to set up; need to attach calibrated fan to air handler cabinet. Accuracy is about 3\%. For this method, an airtight barrier is required between the return plenum and air handler cabinet.

5. Calibrated flow plate - next most accurate (7\%); easy to set up and use; easy to adjust for mismatched pressures. A filter slot or other suitable insertion location is required at the air handler.

Key takeaways from this presentation were:

1. Direct air flow measurement in the field is a more accurate measure than temperature rise or external static pressure measurement when adjusting furnace blowers.

2. The calibrated flow plate technique is the simplest method to use with acceptable accuracy.

\section{Summary}

Larry Brand thanked all the panel members and participants on the phone for their valuable contributions. Gaps and barriers identified and key research questions to be addressed are included in the key takeaway section for each presenter. While not all research questions were addressed, the following expert advice can be drawn from this meeting:

- How do installed efficiency and AFUE differ?

AFUE is measured under controlled laboratory conditions with precise instruments that cannot be replicated in the field. Installed efficiency can vary at least a couple of percentage points if temperature rise is too high (poor adjustment and undersized ducts) and if there is significant oversizing (BEopt algorithm). Fan power is not a part of AFUE, but can significantly increase with undersized ductwork, low external static for PSC motors, and very high external static for ECM motors. Testing is needed to verify these findings.

- What are common installation issues affecting efficiency and how are they addressed?

Efficiency in the field is impacted by furnace oversizing, undersized ducts, and poor fan speed adjustment at installation. To address these issues, minimize oversizing through the use of a good sizing tool, modify ducts (typically adding an additional return drop), and properly follow the manufacturer's installation instructions.

Although not part of the AFUE, electric power for circulating air blowers and inducers are impacted by undersized ducts and oversized vent pipes. Modifying the duct system as above and installing the minimum vent diameter and length permitted by the manufacturer's installation instructions address these areas.

- How do researchers evaluate field performance?

Field performance is difficult to measure with handheld devices and particularly 
difficult for condensing furnaces where the latent component cannot be measured. The best field performance is achieved by following manufacturers' installation instructions for rise, rate, and external static pressure adjustments. Air flow is best measured using a flow plate to provide improved diagnostics.

\section{- What type of furnace gives the best performance in difficult installations?}

a. Single stage furnaces are the most cost-effective and provide good performance for installations without very high external static pressure.

b. Two-stage (and step-modulating furnaces) offer advantages in improved partload efficiency, longer on-times at lower rate to improve comfort/reduce temperature stratification in the space, and reduced fan power at low input. These furnaces provide better efficiency for installations where oversizing for recovery from deep setback is required or where better mixing is needed.

c. Step modulating furnaces offer an additional comfort advantage in that they produce rated air flow at higher external static pressures for installations with significantly undersized and un-repairable ductwork. In addition, ECM blower motors use less power than the PSC motors in two-stage furnaces at the same airflow. Newer step modulating furnaces offer a three-stage burner for better part-load efficiency than two-stage furnaces. These furnaces offer the best performance for all cases but at the highest price.

\section{Meeting Aftermath and Next Steps}

The feedback from meeting participants was decidedly positive. The results of this meeting were shared with attendees at the Building America Technical Meeting in Denver, Colorado, in August 2011, and were the basis for several conversations with manufacturers regarding improvements to the ASHRAE AFUE test procedure.

Thirty-three individuals from eighteen organizations attended the webinar, a good turnout for an Expert Meeting. There were only a few questions and comments from the attendees, much less than anticipated. PARR recommends that future Expert Meetings be conducted only in-person to foster interaction and improve the exchange of ideas.

Research topics identified during the expert meeting and under consideration for 2012 and beyond include:

- Comparing current field efficiency measurements from installing contractors and lab AFUE measurements on the same furnace removed from the field.

- Updating the part load performance curves with modern furnace types (proposed to Oak Ridge National Laboratory).

- Expanding blower power consumption measurements for external static pressures from 0.2 to 0.8 inches water column.

- Measuring inducer motor power with several lengths and diameters of vent pipe allowed by the manufacturers installation instructions. 


\section{Acknowledgments}

PARR would like to thank all the attendees for their participation in the meeting, especially our panel members. We also want to thank Gail Werren from NREL for assistance in preparing the webinar script and hosting the meeting. 


\section{Appendix I: Meeting Slides}

The first page of each presenter's slides is shown in this Appendix. The full presentations and webinar recording are provided at: http://www.baparr.net and accompany this report on the Building America website:

http://www1.eere.energy.gov/buildings/building_america/meetings.html.

\section{Welcome}

Larry Brand from the Gas Technology Institute welcomed the panel and participants and introduced the topic of the Expert Meeting.

\section{Expert Meeting - Maximizing the Installed Performance of High-Efficiency Gas Furnaces}

Larry Brand

Gas Technology Institute

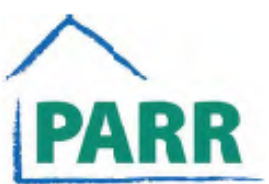

The Partnership

for Advanced

Residential Retrofit

\section{July 28, 2011 \\ Expert Meeting Webinar}




\section{Presentation 1 - U.S. DOE Building America Overview}

Stacey Rothgeb from the National Renewable Energy Laboratory presented an overview of the Building America program.

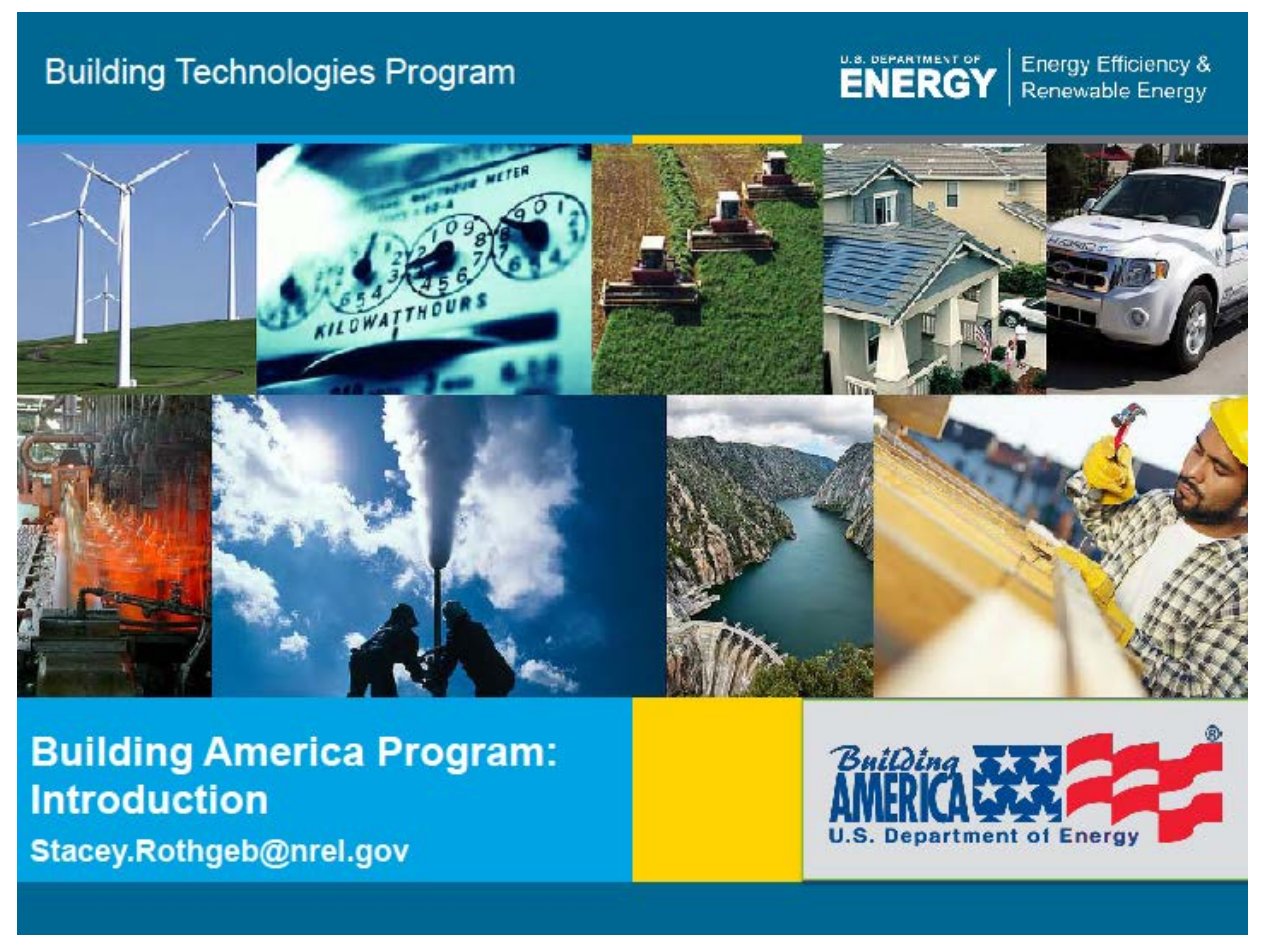

\section{Presentation 2 - Introduction to PARR}

Larry Brand from the Gas Technology Institute presented an overview of the PARR team.

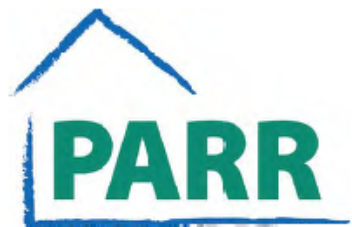

\section{Introduction to PARR}

The Partnership for Advanced Residential Retrofit

Larry Brand

Gas Technology Institute Larry.Brand@gastechnology.org 847.768.0968
Ryan Kerr

Gas Technology Institute

Ryan.Kerr@gastechnology.org

224.735 .0264 


\section{Presentation 3 - GTI Lab Testing}

Larry Brand from the Gas Technology Institute presented recent laboratory research on condensing furnaces.

\section{Buildings Technologies Program $\quad$ EswERGYY}

\section{Installed Performance of High-Efficiency Gas \\ Furnaces - GTI Lab Testing}

Larry Brand

Gas Technology Institute

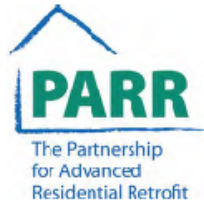

\section{July 28, 2011}

Expert Meeting Webinar

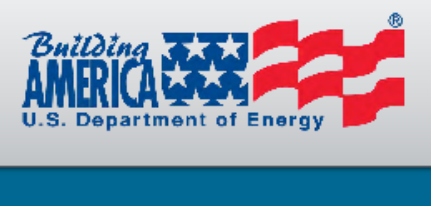

\section{Presentation 4 - National Laboratory Perspective}

Jeffrey Munk from Oak Ridge National Laboratory (ORNL) presented a compilation of research from the national labs.

\section{Lessons from the \\ Lab}

Jeffrey D. Munk

munkjd@ornl.gov

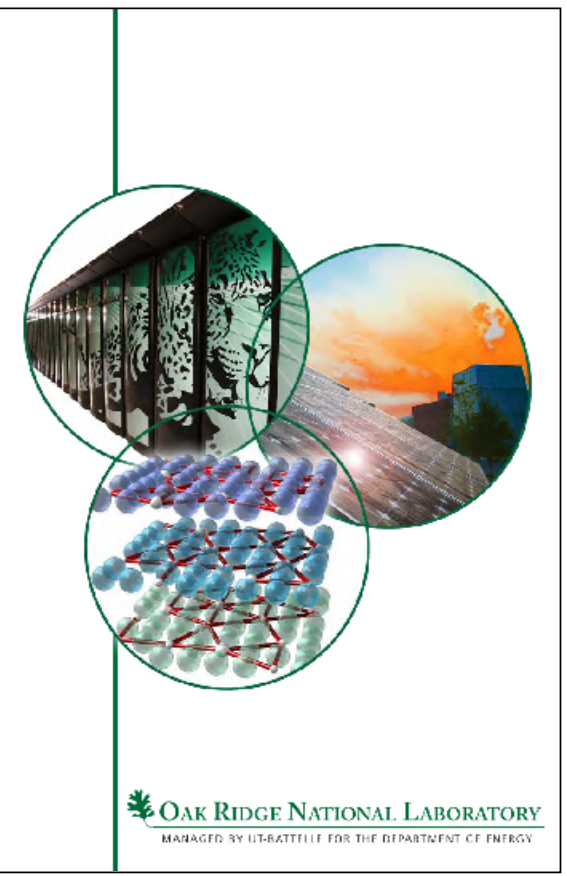




\section{Presentation 5 - Expert Manufacturer Advice - Carrier}

Paul Haydock from United Technologies - Carrier, presented a manufacturers perspective on the issue.

\section{Buildings Technologies Program ENERGY}

\section{Expert Manufacturer Advice - How to Get the Best Installed Performance}

Paul Haydock

Carrier

\section{July 28, 2011}

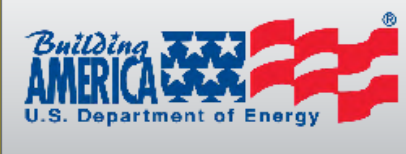

\section{Presentation 6 - Expert Manufacturer Advice - Trane}

Steve Kowalski and Jim VerShaw from Trane presented an additional manufacturers perspective on the issue.

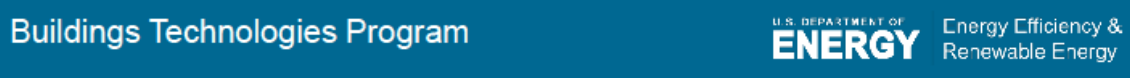

\section{Expert Manufacturer Advice - How to Get the Best Installed Performance}

Jim VerShaw, Stephen Kowalski
Trane

\section{July 28, 2011}

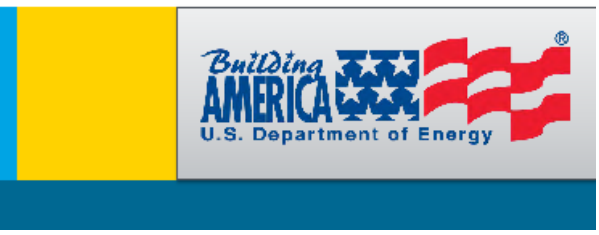


Presentation 7 - Expert Installer Advice from Bartholomew Heating and Cooling Brad Bartholomew from Bartholomew Heating and Cooling presented tips and guidelines from the installer perspective.

\title{
Keys to achieving the best installed performance from high efficiency furnaces
}

Unit efficiency is not the same as delivered efficiency.

There are barriers in the field to achieving the best delivered efficiency.

\section{Date July 28, 2011}

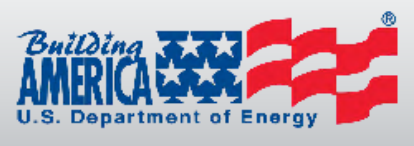

Presentation 8 - Measuring Air Handler Flow in the Field

Paul Francisco from the University of Illinois Building Research Council presented the results of his research on measuring air flow in the field.

\section{Air Handler Flow Measurement: What Works and What Doesn't}

\author{
Paul W. Francisco
}

Building Research Council 


\section{Appendix II: Meeting Flyer}

U.S. Department of Energy, Building America

Partnership for Advanced Residential Retrofit

Topic: "Expert Meeting Webinar on Achieving the Best Installed

Performance from High-Efficiency Residential Gas Furnaces"

When: Thursday July 28, 2010; 1 p.m. to 4 p.m. Central

Link to Webinar:

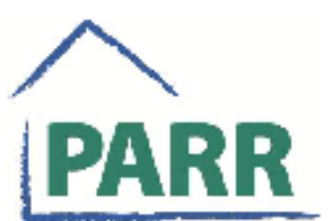

The Partnership

for Advanced

Residential Retrofit

https//www.mymeetings.com/nc/ioin_php?i=PW3243467\&p=2854289\&:=c

Dial-in Number: 877-951-7311 Passcode: 2854289

Objective: The objective of this Expert Meeting is to identify installation practices that provide the best installed efficiency for residential gas furnaces, explain how AFUE and field efficiency can differ, and investigate the impact of installation practices on the long-term performance of the furnace.

Summary: The Partnership for Advanced Residential Retrofit (PARR) Building America (BA) team is conducting research on best practices for installation of high-efficiency gas furnaces. PARR is testing three types of high-efficiency furnaces in the lab under several installation scenarios. These tests are expected to show how variations in installation practices can

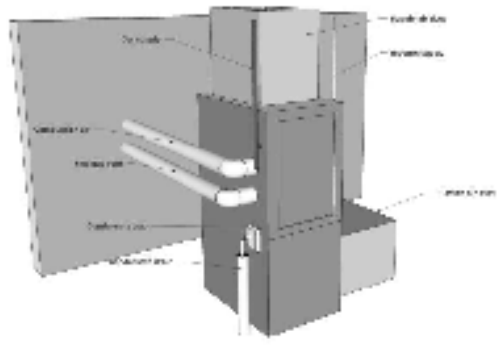
impact AFUE when measured according to ASHRAE standard 103. Several BA teams are performing field-efficiency tests under less-controlled conditions. In this Expert Meeting, speakers from the Gas Technology Institute, furnace manufacturers, an installing contractor, Oak Ridge National Lab, and the University of Illinois Building Research Council will provide their perspectives on methods to achieve the best installed performance.

Questions to be answered:

- How do installed efficiency and AFUE differ?

- What are common installation issues affecting efficiency and how are they addressed?

- How do researchers evaluate field performance?

- What type of furnace gives the best performance in difficult installations?

Attendees: Manufacturers, HVAC Installers, National Laboratories, Building America Teams, DOE, PARR Partners. 
Agenda:

1. Introduction to Building America (Stacey Rothgeb, NREL)

2. Introduction to the Partnership for Advanced Residential Retrofit (Larry Brand, GTI)

3. PARR High Efficiency Furnace Testing - Test Plan, Results to Date, Future Plans (Larry Brand, GTI)

4. Expert Manufacturer Advice - How to Get the Best Installed Performance (Paul Haydock, Carrier; Steve Kowalski/Jim VerShaw, Trane)

5. Expert Installer Advice - How to Get the Best Installed Performance - Lessons from the Field (Brad Bartholomew, Bartholomew Heating and Cooling)

6. Expert National Lab Advice - How to Get the Best Installed Performance - Lessons from the Lab (Jeff Munk, Oak Ridge National Laboratory)

7. Expert Field Measurement Advice - Measurement of Air Handler Flow in the Field (Paul Francisco, University of Illinois Building Research Council)

8. Q\&A and Discussion

9. Conclusion

The Panel:

Stacey Rothgeb is a Building America Research Coordinator at the National Renewable Energy Laboratory.

Larry Brand is an R\&D Manager at Gas Technology Institute and Principal Investigator for the Partnership for Advanced Residential Retrofit Building America team.

Paul Haydock is Manager of Heating Products at United Technologies Carrier.

Steve Kowalski is Engineering Manager at Trane.

Jim VerShaw is Chief Engineer Residential Solutions at Trane.

Brad Bartholomew is the Owner of Bartholomew Heating and Cooling, an installing contractor in Kalamazoo Michigan.

Jeffrey Munk is Research Staff in the Building Equipment Research Group at Oak Ridge National Laboratory working on residential products.

Paul Francisco is a researcher with the Building Research Council at the University of Illinois in Urbana-Champaign where he focuses on residential ventilation and air-side research.

\section{Contact:}

Larry Brand, larry.brand@gastechnology.org

Ryan Kerr, rvan.kerr@gastechnology_org

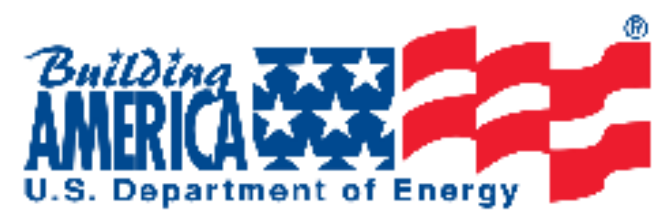




\section{References}

ANSI z223.1/NFPA 54, International Fuel Gas Code, International Code Council, 2012. Also available from the National Fire Protection Association.

ASHRAE Handbook 2008, HVAC Systems and Equipment, Chapter S32, Furnaces

ASHRAE Standard 103 Method of Testing for Annual Fuel Utilization Efficiency of Residential Central Furnaces and Boilers (ANSI Approved), 2007

Manual D - Residential Duct Systems, Air Conditioning Contractors of America, 2009

Manual J Residential Load Calculation Air Conditioning Contractors of America, 2006

Standard for the Installation of Warm Air Heating and Air-Conditioning Systems, 2009 Edition, NFPA 90B

Title 10, Code of Federal Regulations, Chapter II Part 430 Appendix N, Subpart B Uniform Test Method for Measuring the Energy Consumption of Furnaces, January 1, 2001 


\section{U.S. DEPARTMENT OF Energy Efficiency \& ENERY Renewable Energy}

